\title{
Comparative Study between Laparoscopic Common Bile Duct Exploration and Endoscopic Retrograde Cholangiopancreatography Plus Laparoscopic Cholecystectomy for Choledocholithiasis
}

\author{
MAHMOUD RADY, M.Sc.**; MOHAMED M. SALEM, M.D.*; MOHAMED E. ESMAT, F.R.C.S.** and \\ YASER AMER, M.D.* \\ The Department of General Surgery, Faculty of Medicine, Al-Azhar University, Cairo* and Theodor Bilhariz Research Institute, \\ Giza**, Egypt
}

\begin{abstract}
Background: Overall, $5 \%$ to $15 \%$ of patients undergoing cholecystectomy for cholelithiasis have concomitant bile duct stones, and the incidence of choledocholithiasis increases with age. Endoscopic Retrograde Cholangiopancreatography (ERCP) with consequent Laparoscopic Cholecystectomy (LC) has been the favored approach for the treatment of choledocholithiasis for quite a long time; however in the course of recent years, Laparoscopic Common Bile Duct Exploration (LCBDE) has been offered to patients with suspected choledocholithiasis.

Aim of Study: The aim of this work is to compare the efficacy, safety, and the surgical outcomes of LCBDE with ERCP followed by laparoscopic cholecystectomy and determine the most appropriate approach for patients with choledocholithiasis.

Patients and Methods: A prospective randomized clinical study was carried out from March 2017 to September 2018. It included 50 patients with cholecysto-choledocholithiasis who were divided into two groups: Group A (25 patients) included patients who underwent laparoscopic transcystic common bile duct exploration and stone extraction with LC in one stage, and Group B (25 patients) included patients who underwent endoscopic retrograde cholangiopancreatography for CBD stone extraction followed by LC in two stages. The Common Bile Duct (CBD) stone clearance rate, post-operative bile leakage, post-operative morbidity, mortality, overall hospital stay, and patient satisfaction were analyzed.
\end{abstract}

Results: $\mathrm{LCBDE}$ and $\mathrm{ERCP}+\mathrm{LC}$ were similar in terms of clearance rate, operative time postoperative complications, retained CBD stones, and postoperative length of stay, but there was a significant difference in number of procedures and patient satisfaction.

Conclusion: Although both approaches have equivalent success rates, LCBDE is better in terms of fewer procedures, and better satisfaction compared with ERCP + LC. Our study suggests that one-stage management is the treatment of choice for patients with cholecystocholedocholithiasis.

Correspondence to: Dr. Mahmoud Rady, E-Mail: dr.rady88@yahoo.com.
Key Words: Bile duct stones - Laparoscopic common bile duct exploration - Laparoscopic cholecystectomy - Endoscopic retrograde cholangiopancreatography.

\section{Introduction}

IN general, $5 \%$ to $15 \%$ of patients experiencing cholecystectomy for cholelithiasis have corresponding bile duct stones, and a little rate of patients will develop CBD stones after cholecystectomy. Frequency of choledocholithiasis increments with age. Around $20 \%$ to $25 \%$ of patients more established than age 60 with symptomatic gallstones have stones in the CBD and in the gallbladder [1] Subsequently, bile duct stones and their treatment constitute an imperative clinical issue. The essential objective in administration of choledocholithiasis is to get complete clearance of the common duct and cholecystectomy, when shown [2]. Alternatives for management of Common Bile Duct Stones (CBDS) are expanding with advancement of new innovations for conclusion and treatment. Management of symptomatic or unexpectedly found choledocholithiasis is still dubious. There is no evident agreement on the best restorative approach (endoscopic versus surgical) [3]

Pre-operative endoscopic retrograde cholangiopancreatography and Endoscopic Sphincterotomy (ES) are safe and successful choices for evacuating CBDS as a rule, yet not withstanding when clinical, biochemical, and ultrasound criteria are utilized; just $10 \%$ to $60 \%$ of patients will have stones on ERCP. Accordingly, extremely numerous superfluous ERCP are being performed. Truth be told, one of the best preventive measures to diminish ERCP confusions is not to perform it on the off chance that it is superfluous [4]. Utilization of intraoperative ERCP has gradually expanded among different 
endoscopic gatherings, in light of the fact that the move of ERCP from the Endoscopy Unit to the operating room has a short learning curve (endoscopic gatherings with mastery in pre-operative and post-operative ERCP) without the high specialized necessities required by laparoscopic administration of the bile duct $[\mathbf{5 , 6}]$.

Laparoscopic Common Bile Duct Exploration (LCBDE) was presented more than 15 years back and different surgical gatherings have demonstrated that it has a high achievement rate and is similarly as productive and protected as pre-operative or postoperative ERCP related with Laparoscopic Cholecystectomy (LC), in this way staying away from the need to play out extra methods [7,8]. After LCBDE, primary closure or T-tube drainage will be connected by the state of CBD and experience of surgeon. In 1991, Phillip initially announced the procedure of LCBDE and T-tube drainage in treatment of CBD calculi experienced amid laparoscopic cholecystectomy [9]. In recent years, there have been many articles published about the efficacy and safety of LCBDE compared with ERCP $[10,11]$

\section{Material and Methods}

This prospective clinical study was carried out from March 2017 to September 2018. It included 50 patients with concomitant GB stones and CBD stones who were divided into two equal groups: Group A (25 patients) underwent LTCBDE and LC in one stage, and Group B (25 patients) underwent ERCP for CBD stone extraction followed by LC in two stages. The study was approved by the Local Ethics Committee and conducted in accordance to the Helsinki II Declaration. An IRB form and written consent form was obtained from all patients after detailed explanation of the procedures and its possible complications. The main inclusion criteria were classic biliary-type pain, ultrasonographic demonstration of cholecystolithiasis, common bile duct diameter more than $6 \mathrm{~mm}(>5 \mathrm{~mm}$ up to 50 years, then $5+1 \mathrm{~mm}$ per decade) by ultrasonography or demonstration of CBD stones by USG or MRCP or EUS, intrahepatic duct dilation as determined by ultrasonography or CT scan, platelet count more than $100000103 / \mu \mathrm{L}$ and prothrombin time less than $3 \mathrm{sec}$. of control. The main exclusion criteria were evidence of cholangitis and pancreatitis, evidence of cirrhosis, liver mass or abscess, neoplasm, suppurative or necrotizing cholecystitis, gallbladder empyema, or perforation.

All patients of our study were evaluated clinically before the operation and underwent standard laboratory investigations (complete blood count, prothrombin time, partial thromboplastin time, international normalized ratio, liver function tests, serum amylase, and lipase), as well as radiological study, including abdominal ultrasonography, MRCP and EUS that were performed for patients with suspected CBD stones (elevated bilirubin and liver enzymes or ultrasound suspicion of CBD stones).

\section{The operative technique in Group (A):}

Prophylactic broadspectrum intravenous antibiotics with third generation cephalosporin was given at the time of induction. Routine 4 port Reddick laparoscopic cholecystectomy was performed using open method for induction of pneumo-peritoneum. Insertion of the umbilical port by infra-umbilical incision using the Hasson technique to introduce $10 \mathrm{~mm}$ port was done, then introduction of $\mathrm{Co}_{2}$ pneumoperitoneum maintaining the pressure at $12-15 \mathrm{~mm}-\mathrm{Hg}$. This was followed by insertion of another three ports, $10 \mathrm{~mm}$ epigastric port and two $5 \mathrm{~mm}$ ports one just lateral to rectus muscle at right midclavicular line opposite to fundus and the other port at right anterior axillary line at the level of the umbilicus.

After identification of cystic duct and artery was done, intra operative ultrasound was performed to check the integrity of the common bile duct. The Laparoscopic Ultrasound (LUS) probe was inserted through the umbilical or the epigastric port Fig. (1). A distal clip was applied to the duct near the gall bladder neck securing the infundibulocystic junction. A small incision in the cystic duct was performed near to the clip using laparoscopic micro-scissors and the duct milked using the blades of Maryland forceps to ensure clearance of cystic duct from stones. The cystic duct was dilated by the tip of Maryland, then cannulated using a front tipped, saline flushed, size 5 ureteric catheter introduced through a cholangioclamp then screened with a C-arm during the injection Fig. (2).

After confirmation of choledocholithiasis was done and according to Table (1) we proceed to transcystic approach Figs. $(3,4)$ or choledochotomy approach Figs. $(5,6)$.

\section{Transcystic approach Figs. $(3,4)$ :}

The catheter was removed and a dilator (through the epigastric port) into the cystic duct and dilatation of the cystic duct was carried out. Instrumental stone extraction was performed using a three-wire soft Dormia basket under fluoroscopic guidance (safer for ensuring stone capture and avoiding instrumental CBD injury) or under visual cholangioscopic guidance (especially for small stones). 
The assessment of complete stone clearance is performed in by control cholangiography or by using the flexible choledochoscope.

\section{Choledochotomy approach Figs. (5,6):}

The anterior wall of the CBD was additionally dissected within the porta hepatis, by using blunt dissection (avoiding the use of electrocautery close to the CBD). A longitudinal incision was made into the CBD after having blown up the CBD with saline solution through the transcystic cholangiographic catheter. The size of the incision was dependent on the size of the largest CBD stones to be extracted from the CBD. Instrumental stone extraction and stone clearance assessment were done as transcystic approach. Primary CBD closure was done when there is no doubt about the complete CBD vacuity. External biliary drainage was done by using T-tube exteriorized through the site of the most lateral trocar. Closure of the choledochotomy is performed by using interrupted sutures with PDS 4-0 stitches. At the end of the suturing, a watertightness test is employed by blowing the CBD through the TC cholangiographic catheter, before clipping the $\mathrm{CD}$ or through the T-tube. Thereafter, cholecystectomy was completed by dissecting the GB from its bed using diathermy hook. Drain was inserted in the subhepatic region. The patient was discharged at postoperative 2-3 days. Control cholangiography was done at postoperative day 10 to exclude a residual CBD stones or a biliary leak.

\section{Technique of endoscopic stone extraction:}

The procedure was performed with the patient under intravenous sedation. The ERCP procedure was performed with a side-viewing duodenoscope. Selective cannulation of the bile duct was achieved using a wire-guided sphincterotome and a hydrophilic guidewire. After guidewire assisted cannulation, a contrast dye was injected to confirm the presence of CBD stones. For extraction of the stones, a biliary sphincterotomy was performed

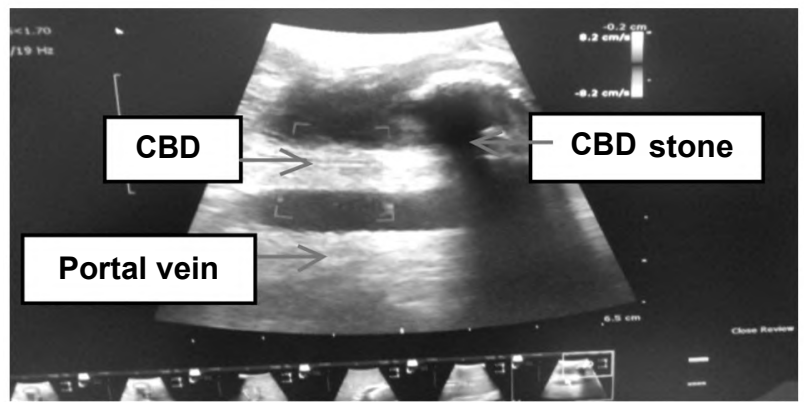

Fig. (1): LUS showing CBD hyperechoic stone with posterior acoustic shadow. using a combination current of cutting and coagulation. The stones were extracted with the help of a Dormia basket or an extraction balloon Fig. (7). A check cholangiogram was performed to confirm complete clearance of the bile duct. The patients were kept under observation for 6-8h after the procedure. The patients were given preprocedure, oral, broad-spectrum antibiotics from the day before the procedure to 5 days after it. After endoscopic extraction of the CBD stones, the patients underwent LC in another session.

All of the patients were scheduled for postoperative follow-up at 1 week, 1, 6 months or at any time if symptoms developed. The presence of pain and its severity, condition of the wound, history of jaundice, and any other problems were noted. At 1-month follow-up, liver function tests and abdominal ultrasound were performed to assess the status of the CBD. The surgical times, surgical success rates, post-operative complications, retained common bile duct stones, post-operative lengths of hospital stay, pain score and satisfaction score were denoted for all patients in Group (A) and (B).

\section{Statistical analysis:}

Collected data were tabulated. Quantitative data were expressed by the mean \pm standard deviation and qualitative data were expressed as number and percent $(\%)$. $t$-student test was used to compare numerical data and Chi-square test was used to compare qualitative data and $p$-value was considered to be significant if it was $<0.05$.

Table (1): The indications of various approaches of LCBDE.

\begin{tabular}{ll}
\hline Transcystic (TC) approach & Choledochotomy approach \\
\hline - A patent cystic duct & - Dilated CBD more than 7-8mm \\
- A limited number of stones & - Accessible porta hepatis \\
- Small stone size (less than cystic & \\
duct size) & \\
- Stones located below CD-CBD & \\
junction & \\
- Adequate biliary anatomy of the & \\
CD-CBD junction (the ideal \\
case is a perpendicular angle of \\
insertion of CD into the CBD)
\end{tabular}

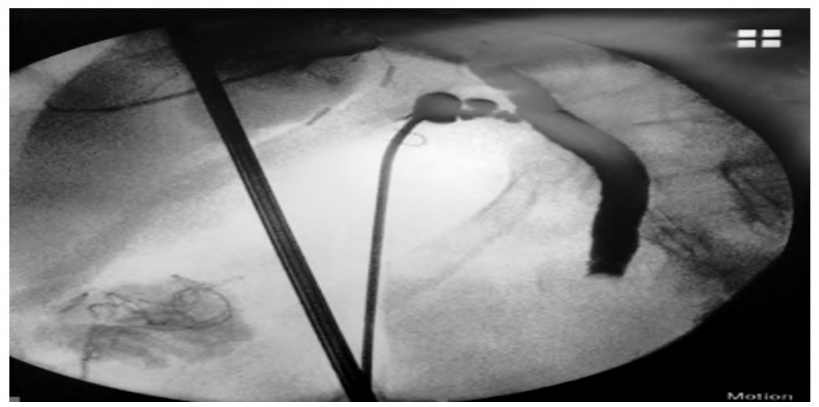

Fig. (2): IOC showing a filling defect in CBD. 


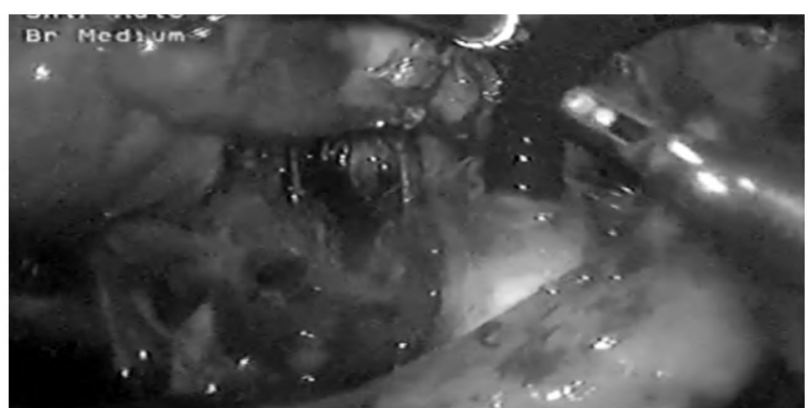

Fig. (3): Visualization of the CBD using the choledochoscope.

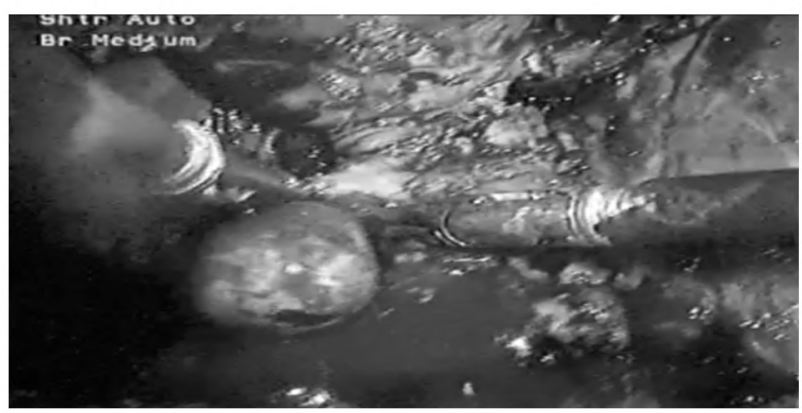

Fig. (5): Gentle stone expression.

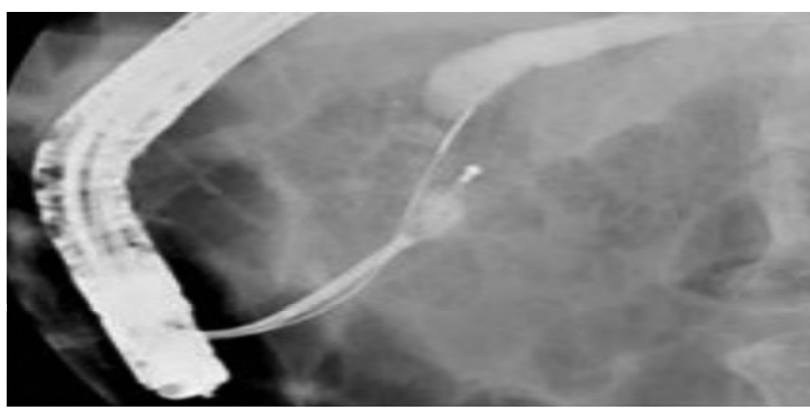

Fig. (7): Radiographic view of basket stone extraction.

\section{Results}

During the study period, March 2017 through Sep. 2019, a total of 50 patients were randomized for the treatment of CBD stones. 25 patients were randomized to LCBDE + LC (Group A) and 25 patients were randomized to ERCP + LC (Group B).

This study was carried out on 50 patients, 9 males (30\%) and 41 females (70\%). Their ages ranged between 21 and 70 years with a mean age of 47.24 years in Group (A), 44.76 years in Group (B). The most common clinical presentations in patients of this study are shown in Table (2).

There was disturbance in liver functions in most of cases, elevated serum bilirubin level was detected in 30 patients $(60.0 \%)$, elevated alkaline phosphatase and Gamma Glutamyl Transeferase (GGT) levels in 35 patients $(70.0 \%)$, elevated Serum Glutamic Oxaloacetic Transaminase (SGOT)

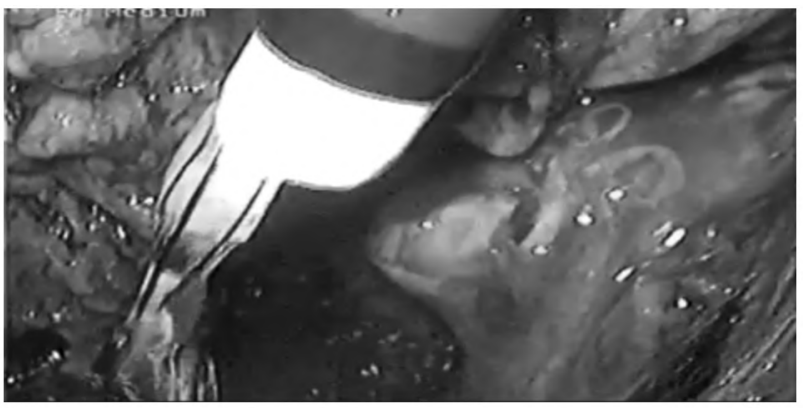

Fig. (4): Stone removal using the dormia basket.

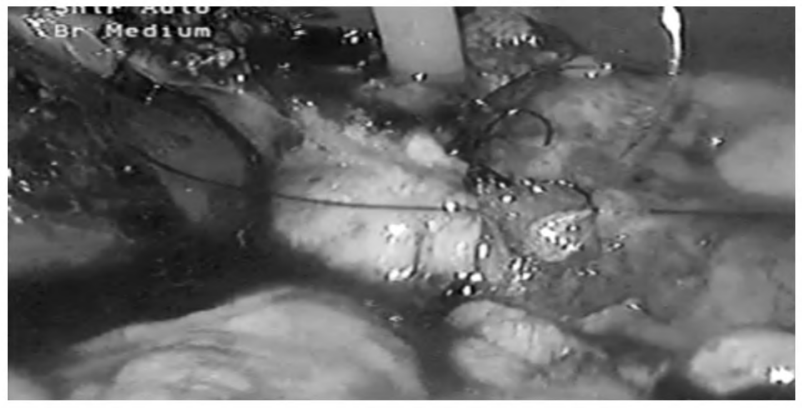

Fig. (6): Closure of CBD over T tube.

and Serum Glutamic Pyruvic Transaminase (SGPT) in 35 patients (70.0\%). The results of the imaging studies were shown in Table (3).

Intraoperative cholangiography was done routinely for all patients of both groups and it revealed stones in 24 patients in Group (A) (96\% sensitivity), and done for all patients in Group (B) before cholecystectomy and it didn't reveal stones in any patient.

\section{The surgical results: Tables $(4,5)$ :}

In Group (A), the procedures were completed in 21 cases $(84 \%)$. Four cases of $25(16 \%)$ were converted to open CBD exploration and stone extraction followed by T-tube and drain insertion. The $\mathrm{T}$-tube was removed after 10 days following $\mathrm{T}$-tube cholangiography, and the drain was removed on the next day. The reasons for conversion were dense adhesions (two patients), impacted stone (one patient) (the choledochoscope wasn't available) and bleeding (one patient).

One patient in Group A with a diagnosis of retained CBD stones was also considered as failure, This patient underwent LCBDE (choledochal approach + primary closure), she suffered from bile leak one week after surgery, abdominal ultrasound showed retained two CBD stones with no collections and she subsequently underwent successful ERCP and stone clearance. Thus, the actual success rate was 20 of 25 patients ( $80 \%$ ). 
In Group (B), ERCP was successful for 21 of 25 patients $(84.0 \%)$. More than one attempt for complete clearance of the CBD was required for 3 patients (12\%). This was followed by LC after six weeks. LC was completed for 19 of 21 patients $(85.7 \%)$, and converted to open cholecystectomy in two cases $(14.3 \%)$. The causes of conversion were bleeding (one case) and dense adhesions (one case). In the remaining 4 patients $(16 \%)$, CBD stones could not be cleared by means of ERCP. The causes of ERCP failure were unsuccessful cannulation (one patient), inability to remove impacted CBD stones (one patient), impacted dormia basket (one patient). All of them underwent LCBDE and stone extraction with cholecystectomy and duodenal perforation (one patient). This patient suffered from small posterior duodenal perforation sealed spontaneously without surgical intervention. After one week this patient underwent LCBDE (choledochal approach) and stone extraction with cholecystectomy and insertion of T-tube and drain. The actual success rate for Group B was 19 of 25 patients $(76 \%)$.

The overall success rate in both groups $(80 \%$ in Group A vs. $76 \%$ in Group B; $p=0.60)$. However, the average number of procedures per patient was significantly lower in Group A than in Group B (1.1 vs. $2.23 ; p<0.001)$.

Table (2): Shows the clinical presentations of studied patients.

\begin{tabular}{llll}
\hline Complaint [n (\%)] & Group A & Group B & $p$-value \\
\hline Right upper quadrant pain & $21(84 \%)$ & $22(88 \%)$ & Ns \\
Jaundice & $8(32 \%)$ & $14(56 \%)$ & 0.15 \\
Pruritus & $5(20 \%)$ & $9(36 \%)$ & 0.34 \\
Fever & $2(8 \%)$ & $5(20 \%)$ & 0.41 \\
Nausea and vomiting & $7(28 \%)$ & $11(44 \%)$ & 0.37 \\
Cholangitis & 0 & $3(12 \%)$ & 0.23 \\
Pancreatitis & 0 & $2(8 \%)$ & 0.48 \\
\hline
\end{tabular}

Table (3): Results of imaging studies done for studied patients.

\begin{tabular}{|c|c|c|c|c|c|}
\hline Imaging studies & Group A & $\begin{array}{l}\text { Sensi- } \\
\text { tivity }\end{array}$ & Group B & $\begin{array}{l}\text { Sensi- } \\
\text { tivity }\end{array}$ & $\begin{array}{c}p- \\
\text { value }\end{array}$ \\
\hline \multicolumn{6}{|l|}{ - Ultrasound [n]: } \\
\hline $\mathrm{CCC}$ & $25 / 25$ & $100 \%$ & $25 / 25$ & $100 \%$ & Ns \\
\hline Dilated CBD & $19 / 25$ & $76 \%$ & $21 / 25$ & $84 \%$ & 0.72 \\
\hline CBD stones & $19 / 25$ & $76 \%$ & $21 / 25$ & $84 \%$ & \\
\hline - MRCP [n] & $12 / 13$ & $92.3 \%$ & & - & \\
\hline - EUS [n] & $11 / 12$ & $91.6 \%$ & $14 / 15$ & $93.3 \%$ & Ns \\
\hline $\begin{array}{l}\text { - Max. size of CBD } \\
\text { stones (mean } \pm \\
\text { SD) }(\mathrm{cm})\end{array}$ & $0.91 \pm 0.072$ & & $1.08 \pm 0.072$ & & 0.35 \\
\hline $\begin{array}{l}\text { - Single CBD } \\
\text { stones }[\mathrm{n}]\end{array}$ & 9 & - & 11 & - & 0.77 \\
\hline $\begin{array}{l}\text { - Multiple CBD } \\
\text { stones [n] }\end{array}$ & 16 & - & 14 & - & \\
\hline
\end{tabular}

Table (4): Operative data of the studied patients.

\begin{tabular}{|c|c|c|c|}
\hline & Group A & Group B & $p$-value \\
\hline $\begin{array}{l}\cdot \text { Number of } \\
\text { procedures per } \\
\text { patient }(\text { mean } \pm \mathrm{SD})\end{array}$ & $1.040 \pm 0.040$ & $2.120 \pm 0.0663$ & $<0.0001$ \\
\hline - Success rate & $20(80 \%)$ & $19(76 \%)$ & 0.52 \\
\hline • Failure rate & $5(20 \%)$ & $6(24 \%)$ & \\
\hline $\begin{array}{l}\text { - Operative time } \\
(\text { mean } \pm \text { SD) }(\min )\end{array}$ & $199.2 \pm 8.601$ & & \\
\hline $\begin{array}{l}\text { Intraoperative } \\
\text { cholangiogram }\end{array}$ & 25 (96\% sensitivity) & $226.4 \pm 14.59$ & 0.11 \\
\hline $\begin{array}{l}\text { - Intraoperative } \\
\text { ultrasound }\end{array}$ & 15 (93\% sensitivity) & & \\
\hline - Choledochoscope & 20 (95\% sensitivity) & & \\
\hline
\end{tabular}

Table (5): Post-operative follow-up of the studied patients.

\begin{tabular}{lccc}
\hline & Group A & Group B & $p$-value \\
\hline - 24h pain score (mean \pm SD) & $6.120 \pm 0.240$ & $6.440 \pm 0.238$ & 0.34 \\
- Hospital stay (mean \pm SD) & $4.440 \pm 0.798$ & $4.920 \pm 0.772$ & 0.66 \\
$\begin{array}{l}\text { (days) } \\
\text { Patient satisfaction score } \\
\text { (mean } \pm \text { SD) }\end{array}$ & $6.60 \pm 0.408$ & $5.20 \pm 0.428$ & 0.02 \\
\hline
\end{tabular}

\section{Discussion}

Bile duct stones are found in $7-20 \%$ of patients with symptomatic gallstones. The nearness of common bile duct stones essentially increases the morbidity, mortality, and expenses of patients with gallstones [12]. The management of CBD stones has experienced different phases of advancement and development, and LCBDE is currently viewed as a better procedure compared with endoscopic extraction of stones, with comparable morbidity and mortality and a shorter hospital stay in fit patients [13]. The undeniable objective of treatment in choledocholithiasis is to accomplish ductal clearance with the least number of mediations, most minimal expense and least morbidity [14].

Conventional surgical treatment involves intraoperative cholangiography to identify the presence of bile duct calculi pursued by choledocholithotomy and T-tube placement. For a long time this strategy offered successful treatment and was related with a morbidity rate of $10-15 \%$, a death rate of $<1 \%$ (in patients under 65 years) and a retained stone rate beneath $6 \%[15]$

Although ERCP is effective and safe, this management option has several disadvantages, including a large number of normal ERCP's performed, up to $86 \%$ when ERCP is performed routinely for all patients and division of the choledochal sphincter in young adults, leading to loss of the normal physiologic barrier, with long term complications such as ampullary stenosis, duodenobiliary reflux, and recurrent stone formation [16] 
It was reported that one stage operations have some benefits, as compared to two stage operations. Morbidity after one-stage operations was only $7.5 \%$ (2 times lower). The reported results of LCBDE when compared to data obtained after the two-stage procedure, show at least identical, rather improved safety for the patient and partial reduction of costs [17]. Postponing laparoscopic cholecystectomy post ERCP makes it difficult to be performed due to the possibility of adhesions at the area of Calot triangle this is in additional risk of second time anaesthesia [18].

Intraoperative cholangiography is an accurate method for detecting common bile duct stones and it helped us greatly in avoiding injury of the bile ducts. It was done for all patients of Group (A) before LCBDE and it revealed stones in 24 patients (95\% sensitivity). Intraoperative ultrasonography was done for $15 / 25$ patients of Group (A) before LCBDE and it revealed stones in 14 patients (93\% sensitivity). These findings were similar to data collected from several studies which denoted that IOC (intraoperative cholangiography) has a sensitivity of $98 \%$ and specificity of $94 \%$ to detection of CBD stones [19].

The success rate for LCBDE in our study was $80 \%$, which was comparable to that reported in the existing literatures (80-98.5\%). Similar study carried out by Hong DF et al., denoted success rate of $80 \%$ [18]. In other studies success rate of $80 \%$ to $95 \%$ were reported [20-22].

Our study showed similar success rates for the single-stage and two-stage procedures ( 80 vs. $76 \%$ ), but the single-stage procedure was better in terms of a less number of procedures and higher patient satisfaction compared with two-stage management. This is consistent with previous research reports $[23,24]$. To date, little agreement has been reached on the rate of CBD stone clearance. One metaanalysis of eight RCTs showed that LCBDE + LC was associated with a higher rate of CBD stone clearance than pre-ERCP + LC $(90.17 \%$ vs. $85.71 \%$, respectively; recent meta-analysis [25] However, a study conducted by Elgeidie et al., showed that pre-ERCP + LC was associated with a higher success rate of CBD stone clearance [26]

There was only one case suffered from retained common bile duct stones among patients belonged Group A (4.5\%). This was in contrary to $12 \%$ of studied patients in the study carried out by Stanley et al., [27]. In the study by Ding et al., the authors reported that LCBDE + LC stones had a lower recurrence rate [28].
In this study our favored technique for LCBDE was the transcholedochal approach and was done for nineteen patients while the transcystic approach was done for six patients as the transcystic approach needs specific cystic duct and stones characters as in (Table 1). The postoperative course after successful transcystic clearance is similar to laparoscopic cholecystectomy alone. This was in agreement with the following studies $[\mathbf{8 , 2 9}]$

In this study we used the choledochoscope for twenty patients and it was helpful to confirm bile duct clearance and to visualize the proximal portion of the CBD with sensitivity (95\%) In the other five cases choledochoscope was replaced (due to some technical problems in the choledochoscope) by fluoroscopic guidance and confirmatory IOC. This was in agreement with Phillips EH et al., who denoted nearly similar efficacy between choledochoscope and fluoroscopic guidance [30]. This was in contrary to Topal B et al., who reported that the use of a flexible choledochoscope is preferable to fluoroscopic guidance [31].

In our study T-tube drainage was done for 10 cases while primary closure was done for 6 cases with no statistical difference between them. This is in agreement with recent studies which show that primary sutures have the same safety and effectiveness as T-tube drainage. This is still controversial. More detailed and higher-quality research on postoperative pancreatitis and bile leakage is necessary in the future [32]

In our study ERCP was successful for 21 of 25 patients $(84.0 \%)$. More than one attempt for complete clearance of the CBD was required for 3 patients (12\%). This was followed by LC after six weeks. LC was completed for 19 of 21 patients $(85.7 \%)$, and converted to open cholecystectomy in two cases $(14.3 \%)$. The actual success rate for Group (B) was 19 of 25 patients (76\%). However other studies denoted that the overall success rate of ERCP/S + LC in experienced hands is well established at about $95 \%$. However, the minimum number of ERCP procedures necessary for competency has been suggested by Vitale et al., to be between 102 and 185 procedures to achieve a success rate of $85 \%$ to $90 \%$ [33]

Our study reported that five patients in Group B were converted from LC to open cholecystectomy following successful ERCP due to adhesions and uncontrollable bleeding. Tis is similar to Allen and Leeth and Donkervoort et al., who reported greater difficulty and higher conversion rates with chole- 
cystectomy after ERCP and the possibility of unpredictable adhesions $[\mathbf{3 4 , 3 5 ]}$.

The mean operative time was shorter in Group (A) than in Group (B) in our study (199.2 \pm 8.6 vs. $226.4 \pm 14.5)$ with no significant difference ( $p=$ 0.114 ). This was similar to previous studies that showed similar results [36,37].

Our study showed no significant difference between Group A and Group B regarding postoperative complications ( $8 \%$ vs. $16 \% ; p=0.66$ ). The complication rates in the literature have not differed significantly between the two strategies. A meta-analysis found the morbidity rates to be $19 \%$ in the single-stage group and $15.2 \%$ in the two stage group, and the difference was not statistically significant [38]

Our study showed no significant difference between Group (A) and Group (B) regarding hospital stay $(4.44 \pm 0.79$ vs. $4.92 \pm 0.77 ; p=0.66)$ and $24 \mathrm{~h}$ pain score $(6.12 \pm 0.24$ vs. $6.44 \pm 0.23 ; p=0.34)$. This is in contrast to other studies which denoted shorter hospital stay in this Group A than Group $\mathrm{B}[18,32,39]$

\section{Conclusion:}

Although both treatment methods have equivalent success rates, the one-stage management is better in terms of fewer procedures, and better overall satisfaction compared with the two-stage approach. In addition, the one-stage management also avoided the risks associated with ERCP and sphincterotomy and kept the sphincter of Oddi intact, and this was associated with a lower risk for late CBD stone formation. Hence, the outcomes of this study suggest that the one-stage management is the treatment of choice for patients with concomitant GB and CBD stones, especially in younger patients who have longer period of risk for recurrence of CBD stones.

\section{Conflict of interest:}

We declared that there is no conflict of interest.

\section{References}

1- THAI H. PHAM and JOHN G. HUNTER: Gallbladder and the Extrahepatic Biliary, in: Schwartz's Principles of Surgery, part II, Specific Considerations, Chapter 33, $10^{\text {th }}$ edition, edited by Charles FB, Dana KA and Timothy RB et al., by McGraw-Hill Companies Inc., p. 13 10-40, 2015.

2- MORI T., SUZUKI Y., SUGIYAMA M. and ATOMI Y.: Choledocholithiasis. In: Bland KI, Büchler MW, Csendes A, et al., editors General Surgery. Principles and International Practice. Second Edition. London: Springer-Verlag London, 1061-73 , 2009.
3- RÁBAGO L.R., CHICO I., COLLADO D., et al.: Singlestage treatment with intraoperative ERCP: Management of patients with possible choledocholithiasis and gallbladder in situ in a non-tertiary Spanish hospital. Surg. Endosc., 26: $1028-34,2012$

4- GHAZAL A.H., SOROUR M.A., EL-RIWINI M., et al.: Single-step treatment of gallbladder and bile duct stones: A combined endoscopic-laparoscopic technique. Int. J. Surg., 7: 338-46, 2009.

5- CHATHADI K.V., CHANDRASEKHARA V., ACOSTA R.D., et al.: The role of ERCP in benign diseases of the biliary tract. Gastrointest. Endosc., 81 (4): 795-803, 2015.

6- EASLER J.J. and SHERMAN S.: Endoscopic Retrograde Cholangio-pancreatography for the Management of Common Bile Duct Stones and Gallstone Pancreatitis. Gastrointest. Endosc. Clin. N. Am., 25 (4): 657-75, 2015.

7- DARKAHI B., LILJEHOLM H. and SANDBLOM G.: Laparoscopic Common Bile Duct Exploration: 9 Years Experience from a Single Center. Front. Surg., 3: 23, 2016.

8- AAWSAJ Y., LIGHT D. and HORGAN L.: Laparoscopic common bile duct exploration: 15-year experience in a district general hospital. Surg. Endosc. [Epub ahead of print], 2015 .

9- HA J.P., TANG C.N., SIU W.T., CHAU C.H. and LI M.K. Primary closure versus T-tube drainage after laparoscopic choledochotomy for common bile duct stones. Hepatogastroenterology, 51 (60): 1605-8, 2004.

10- GUPTA N.: Role of laparoscopic common bile duct exploration in the management of choledocholithiasis. World J. Gastrointest. Surg., 8 (5): 376-81, 2016.

11- QIU J., YUAN H., CHEN S. and WU H.: Laparoscopic common bile duct exploration in cirrhotic patients with choledocholithiasis. Surg. Laparosc. Endosc. Percutan Tech., 25 (1): 64-8, 2015.

12- HUNGNESS E.S. and SOPER N.J.: Management of common bile duct stones. J. Gastrointest. Surg., 10 (4): 612-9, 2006.

13- VINDAL A., CHANDER J., LAL P. and MAHENDRA B.: Comparison between intraoperative cholangiography and choledochoscopy for ductal clearance in laparoscopic CBD exploration: A prospective randomized study. Surg. Endosc., 29: 1030-8, 2015.

14- ZEREY M., HAGGERTY S., RICHARDSON W., et al.: Laparoscopic common bile duct exploration. Surg. Endosc., 32: 2603, 2018.

15- DOLAN J.P., DIGGS B.S., SHEPPARD B.C., et al.: The National Mortality Burden and Significant Factors Associated with Open and Laparoscopic Cholecystectomy: 1997-2006. J. Gastrointest. Surg., Sep. 2, 2009.

16- BANSAL V.K., MISRA M.C., RAJAN K., KILAMBI R., KUMAR S., KRISHNA A., et al.: Single stage laparoscopic common bile duct exploration and cholecystectomy versus two-stage endoscopic stone extraction followed by laparoscopic cholecystectomy for patients with concomitant gallbladder stones and common bile duct stones: A randomized controlled trial. Surg. Endosc., 28: 875$85,2014$.

17- KHARBUTLI and VELANOVICH V.: Management of pre-operatively suspected choledocholithiasis: A decision 
analysis, Journal of Gastrointestinal Surgery, Vol. 12, No. 11, pp. 1973-80, 2008.

18- HONG D.F., XIN Y., CHEN D.W., et al.: Comparison of laparoscopic cholecystectomy combined with intraoperative endoscopic sphincterotomy and laparoscopic exploration of the common bile duct for cholecystocholedocholithiasis. Surg. Endosc., 20 (3): 424-7, 2006.

19- GRINIATSOS J., KARVOUNIS E. and ISLA A.M.: Limitations of fluoroscopic intraoperative cholangiography in cases suggestive of choledocholithiasis, Journal of Laparoendoscopic and Advanced Surgical Techniques, Vol. 15, No. 3, pp. 312-7, 2005.

20- MATTILA A., LUHTALA J., MRENA J., KAUTIAINEN H. and KELLOKUMPU I.: An audit of shortand longterm outcomes after laparoscopic removal of common bile duct stones in Finland. Surg. Endosc., 28: 3451-7, 2014.

21- CHAN D.S., JAIN P.A., KHALIFA A., HUGHES R. and BAKER A.L.: Laparoscopic common bile duct exploration. Br. J. Surg., 101: 1448-52, 2014.

22- ZHANG H.W., CHEN Y.J., WU C.H. and LI W.D.: Laparoscopic common bile duct exploration with primary closure for management of choledocholithiasis: A retrospective analysis and comparison with conventional Ttube drainage. Am. Surg., 80: 178-81, 2014.

23- ZHU H.Y., XU M., SHEN H.J., YANG C., LI F., LI K.W., SHI W.J. and JI F.: A meta-analysis of single-stage versus two-stage management for concomitant gallstones and common bile duct stones. Clin. Res. Hepatol. Gastroenterol., 39 (5): 584-93, 2015.

24- DASARI B.V., TAN C.J., GURUSAMY K.S., MARTIN D.J., KIRK G., McKIE L., DIAMOND T. and TAYLOR M.A.: Surgical versus endoscopic treatment of bile duct stones. Cochrane Database Syst. Rev., 12: Cd003327, 2013.

25- PAN L., CHEN M., JI L., ZHENG L., YAN P., FANG J., ZHANG B. and CAI X.: The safety and efficacy of laparoscopic common bile duct exploration combined with cholecystectomy for the management of cholecystocholedocholithiasis: An up-to-date meta-analysis. Ann. Surg., 268 (2): 247-53, 2018.

26- ELGEIDIE A., ATIF E., NAEEM Y. and ELEBIDY G. Laparoscopic bile duct clearance without choledochoscopy. Surg. Laparosc. Endosc. Percutan. Tech., 25 (5): e152e155, 2015.

27- STANLEY J. ROGERS, JOHN P. CELLO and JAN K. HORN: Prospective Randomized Trial of LC-LCBDE vs ERCP/S_LC for Common Bile Duct Stone Disease, Archsurg., 145: 28-33, 2010.

28- DING Y.M., WANG B., WANG W.X., et al.: New classification of the anatomic variations of cystic artery during laparoscopic cholecystectomy. World J. Gastroenterol., 13: 5629-34, 2007.

29- LEE J. and YOON Y.: Laparoscopic common bile duct exploration using V-Loc suture with insertion of endobiliary stent. Surg. Endosc. [Epub ahead of print], 2015.

30- PHILLIPS E.H., TOOULI J., PITT H.A. and SOPER N.J.: Treatment of common bile duct stones discovered during cholecystectomy. J. Gastrointest. Surg., 12: 624-8, 2008.

31- TOPAL B., AERTS R. and PENNINCKX F.: Laparoscopic common bile duct stone clearance with flexible choledochoscopy, Surg. Endosc., 21: 2317-21, 2007.

32- YUNXIAO LYU, YUNXIAO CHENG, TING LI, BIN CHENG and XIN JIN: Laparoscopic common bile duct exploration plus cholecystectomy versus endoscopic retrograde cholangiopancreatography plus laparoscopic cholecystectomy for cholecystocholedocholithiasis: A meta-analysis. Surg. Endosc., https://doi.org/10.1007/ s00464-018-06613-w, 2018.

33- VITALE G.C., ZAVALETA C.M., VITALE D.S., BINFORD J.C., TRAN T.C. and LARSON G.M.: Training surgeons in endoscopic retrograde cholangiopancreatography. Surg. Endosc., 20 (1): 149-52, 2006.

34- ALLEN N.L., LEETH R.R., FINAN K.R., TISHLER D.S., VICKERS S.M., WILCOX C.M. and HAWN M.T.: Outcomes of cholecystectomy after endoscopic sphincterotomy for choledocholithiasis. J. Gastrointest. Surg., 10: 292-6, 2006.

35- DONKERVOORT S.C., VAN RULER O., DIJKSMAN L.M., VAN GELOVEN A.A. and PIERIK E.G.: Identification of risk factors for an unfavorable laparoscopic cholecystectomy course after endoscopic retrograde cholangiography in the treatment of choledocholithiasis. Surg. Endosc., 24: 798-804, 2010.

36- NOBLE H., TRANTER S., CHESWORTH T., NORTON S. and THOMPSON M.A.: Randomized, clinical trial to compare endoscopic sphincterotomy and subsequent laparoscopic cholecystectomy with primary laparoscopic bile duct exploration during cholecystectomy in higher risk patients with choledocholithiasis. J. Laparoendosc. Adv. Surg. Tech. A, 19: 713-20, 2009.

37- MARTIN D.J., VERNON D.R. and TOOULI J.: Surgical versus endoscopic treatment of bile duct stones. Cochrane Database Syst. Rev., (2): CD003327, 2006.

38- LU J., CHENG Y., XIONG X.Z., LIN Y.X., WU S.J. and CHENG N.S.: Two-stage vs singlestage management for concomitant gallstones and common bile duct stones. World J. Gastroenterol., 18: 3156-66, 2012.

39- SHOJAIEFARD A., ESMAEILZADEH M., GHAFOURI A., et al.: Various techniques for the surgical treatment of common bile duct stones: A meta review. Gastroenterol. Res. Pract., 840208. Epub. 2009 Aug. 6, 2009. 


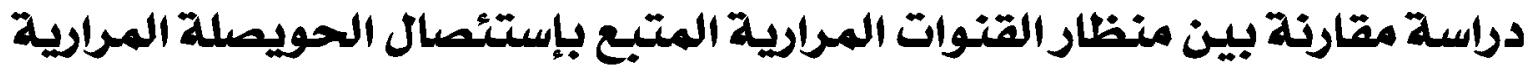

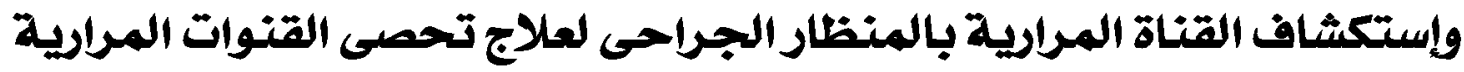

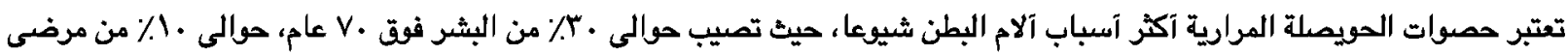

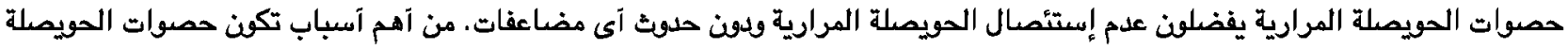

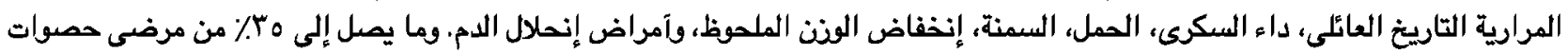

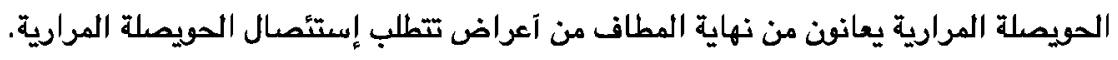

يعتبر المغص المرارى، إلتهاب الحويصلة المرارية الحاد، إلتهاب البنكرياس الناتج عن وجود حصوات، إنسداد القناة المرارية العامة

وإلتهاب القنوات المرارية الناتج عنه من آهم المضاعفات التورات الناجمة عن حصوات التهاب البكريات التصلة المرارية.

من آهم مضاعفات حصوات الحويصلة المرارية إنسداد القناة المرارية العامة حيث تصيب ـ1\%-0 إ من هؤلاء المرضى، ويلاحظ ذلك بصورة شائعة فى الآعمار المتقدمة وخصوصاً فوق سن الفمات النمسين.

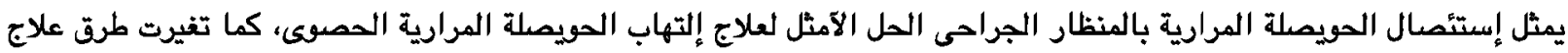

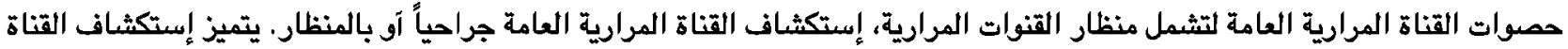

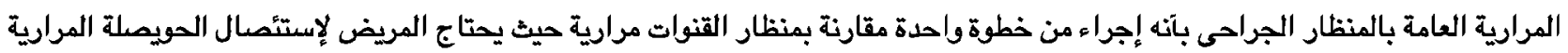
بعد ذلك.

فى السنوات الآخيرة، كانت هناك العديد من المقالات التى نشرت حل فعالية وسيلامة إستكشاف القناة المرارية العامة بإستخدام المنظار الجراحى مقارنة بمنظار القنوات المرانت فناك العيدية

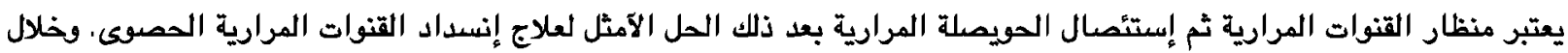

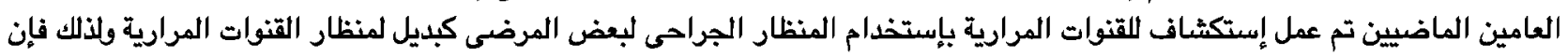
الغرض من هذه الدراسة هو المقارنة بين الطريقتين. 